Article

\title{
A Comparative Study of Corrosion Resistance for HVAF-Sprayed Fe- and Co-Based Coatings
}

\author{
Esmaeil Sadeghimeresht *, Nicolaie Markocsan and Per Nylén \\ Department of Engineering Science, University West, 46153 Trollhättan, Sweden; \\ Nicolaie.Markocsan@hv.se (N.M.); Per.nylen@hv.se (P.N.) \\ * Correspondence: Esmaeil.sadeghimeresht@hv.se; Tel.: +46-520-223-334 \\ Academic Editor: Robert B. Heimann \\ Received: 1 March 2016; Accepted: 25 March 2016; Published: 31 March 2016
}

\begin{abstract}
There is an increasing demand to replace Co-based coatings with cheap and environmentally friendly Fe-based coatings in corrosive environments. The main objective of this work was to evaluate whether Fe-based coatings could present a better corrosion performance than Co-based coatings. Therefore, two types of Fe-based and one type of Co-based coatings with chemical compositions (in wt \%) of Fe-28Cr-16Ni-1.85C (FeNiCrC), Fe-17Cr-12Ni (FeNiCr), and Co-28Cr-1C ( $\mathrm{CoCrC})$ were produced by High Velocity Air Fuel (HVAF) spraying. The corrosion behavior of the coatings was studied comparatively by electrochemical tests in $3.5 \mathrm{wt} \% \mathrm{NaCl}$ solution at $25^{\circ} \mathrm{C}$. The polarization test results showed that the $\mathrm{FeCrNiC}$ coating protected the underlying substrate better than the $\mathrm{CoCrC}$ coating, while the $\mathrm{FeCrNi}$ coating failed to hinder the penetration of corrosive ions. Electrochemical impedance spectroscopy (EIS) measurements revealed that the solution penetrated into the coating through defects, however the corrosion process slowed down due to clogging of the interconnected defects by corrosion products. Increasing the in-flight average particle temperature from $1400{ }^{\circ} \mathrm{C}$ to $1500{ }^{\circ} \mathrm{C}$ led to a denser coating with fewer defects which seemed to improve the corrosion resistance of the $\mathrm{FeCrNiC}$ coating. The high-alloyed Fe-based coatings had the best corrosion protection performance and can thus be recommended as a potential alternative to Co-based coatings.
\end{abstract}

Keywords: thermal spray coating; HVAF; corrosion; polarization; EIS

\section{Introduction}

Corrosion is a serious problem in many industrial components, resulting in catastrophic failure, economic loss, and personal injury [1-3]. To address these problems, many efforts have been made to produce high-performance Co-based coatings providing improved corrosion resistance to a component [4]. However, the drawbacks of Co in terms of cost and environmental restriction have increased the interest to find other materials [5-9]. High-alloyed Fe-based coatings containing a sufficient level of another major alloying element such as $\mathrm{Cr}$ or $\mathrm{Ni}$ would be a cheaper and a more environmentally friendly alternative to Co-based coatings of specific interest in high demanding applications [5,10-13]. Adding minor alloying elements of C or B to high-alloyed Fe-based alloys has been shown to improve both the corrosion and wear resistance of the coatings [14-22].

Thermal sprayed coatings are extensively used to protect components in harsh corrosive environments. High velocity air fuel (HVAF) is a recently introduced thermal spray technique that has been shown be very competitive as an environmental friendly alternative to electrolytic hard chromium (EHC). Coatings sprayed by HVAF have been compared with high-velocity oxy/fuel (HVOF) [11,23-25] sprayed coatings. The HVAF coatings were shown to be superior both regarding corrosion protection and production cost [24,26-28]. The high velocity of the in-flight particles (1000-1200 m/s) in HVAF enables production of very dense coatings with low porosity [29]. Moreover, the low spraying 
temperature (below $2000{ }^{\circ} \mathrm{C}$ ) and short particle dwell time due to the high particle speed lead to minimal feedstock phase transformation and almost inexistent elemental depletion/decomposition of the in-flight particles. Furthermore, the replacement of pure oxygen in the HVOF process with air in the HVAF process, significantly reduces the oxide content in the coatings, which also is desirable in high performance coatings $[27,30]$. Several studies have been performed on HVAF sprayed Fe-based coatings $[2,19,24,28,31,32]$. The coatings have shown high corrosion resistance in different environments such as acid, alkaline, and chloride solutions. High quality microstructures with low oxide content, high retention of the powder chemistry and low porosity have been reported [10].

Several corrosion studies have also been conducted on Co-based coatings $[4,7,33]$. Few studies, however, have been made on low temperature corrosion performance of HVOF sprayed Fe-based coatings. Corrosion studies have previously been performed on coatings sprayed with amorphous Fe-based powders $[28,33,34]$. Studies have also been made on coatings where more complex powder compositions have been used i.e., Fe-based alloys with elements such as $\mathrm{Cr}$ [35]. $\mathrm{Cr}$ is in the latter case added to provide sufficient $\mathrm{Cr}$ dissolved in the austenitic $(\gamma)$ solid solution coating matrix to increase the ability of the alloy to form a thin protective surface oxide layer and also to form hard precipitates in the presence of $C$ to provide wear resistance. A sufficiently high $\mathrm{Cr}$ and $\mathrm{C}$ content in the alloy is thus feasible to provide both a good corrosion and a good wear resistance [36].

The promising results with the HVAF process [37], make it of interest to study corrosion behavior of high-and low-alloyed Fe-based coatings produced by HVAF as a potential alternative to Co-based coatings. In the present study, both Fe- and Co-based coatings were deposited by the HVAF process and their microstructure and corrosion behavior investigated and compared. Corrosion properties were studied with open-circuit potential (OCP), polarization, and electrochemical impedance spectroscopy (EIS) measurements, and the role of corrosive species and the type of corrosion products were evaluated by scanning electron microscope and X-ray energy dispersive spectroscopy (SEM/EDS) and X-ray diffraction (XRD).

\section{Materials and Methods}

\subsection{Substrate Material}

Domex 355 steel (0.10C-0.03Si-1.50Mn-0.02P-0.01S-0.20V-0.15Ti wt \%) in the shape of a ring was used as the substrate material. The ring had an inside diameter of $100 \mathrm{~mm}$ and a thickness of $2 \mathrm{~mm}$. The ring was mounted on a rotating carousel and coated with sequential spray passes. The substrates were degreased in acetone and, grit blasted with alumina grits (mesh 220) to clean and roughen the surface before spraying. The samples were cut into square plates of the size of $10 \times 10 \times 2 \mathrm{~mm}^{3}$ before each corrosion test. The samples were thereafter degreased and rinsed in high-purity water, followed by ethanol cleaning and air-drying.

\subsection{Coating Materials}

Three gas-atomized Fe- and Co-based powders with particle sizes between 20 and $53 \mu \mathrm{m}$ were used. The chemical compositions as well the densities of the powders are shown in Table 1. All powders had a fairly spherical morphology as shown in Figure 1.

Table 1. Powder composition and apparent density.

\begin{tabular}{|c|c|c|c|c|c|c|c|c|c|c|}
\hline \multirow{2}{*}{ Powder } & \multicolumn{9}{|c|}{ Composition (wt \%) } & \multirow{2}{*}{$\begin{array}{c}\text { Apparent } \\
\text { Density }\left(\mathrm{g} / \mathrm{cm}^{3}\right)\end{array}$} \\
\hline & $\mathrm{Cr}$ & $\mathrm{Ni}$ & $\mathrm{C}$ & $\mathbf{W}$ & $\mathrm{Si}$ & Mo & Mn & $\mathrm{Fe}$ & Co & \\
\hline 1 & 28.0 & 16.0 & 1.85 & - & 1.2 & 4.4 & 1.5 & Bal. & - & 4.2 \\
\hline 2 & 17.0 & 12.0 & 0.01 & - & - & 2.5 & 1.5 & Bal. & - & 4.1 \\
\hline 3 & 28.0 & 1.5 & 1.00 & 4.4 & 1.1 & - & - & 0.5 & Bal. & 4.6 \\
\hline
\end{tabular}




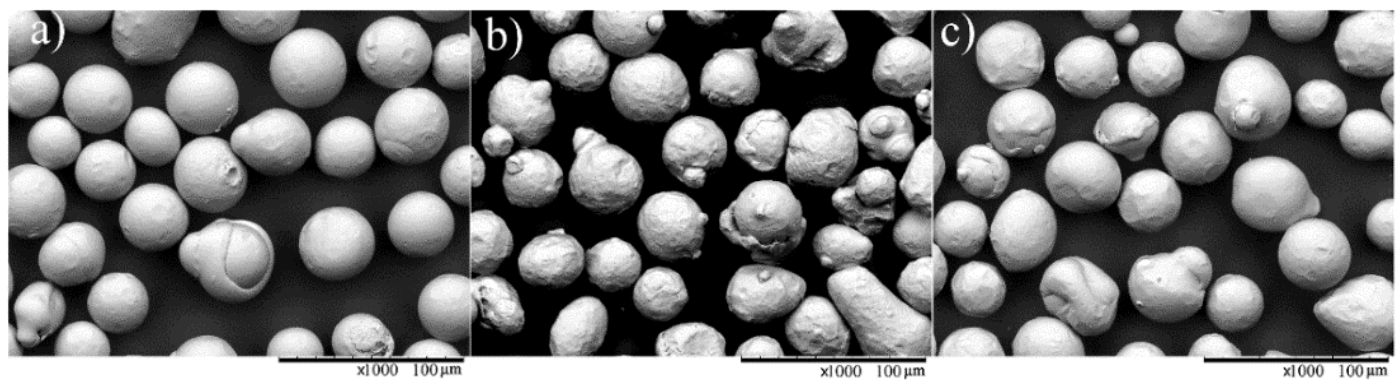

Figure 1. Scanning electron microscopy (SEM) micrographs of the powders (a) FeNiCrC; (b) FeNiCr and (c) $\mathrm{CoCrC}$.

\subsection{Solution Preparation}

The experiments were performed in $3.5 \mathrm{wt} \% \mathrm{NaCl}$ (seawater) solution. All the chemical solutions were used from analytical grade reagents with distilled water. The solutions were in an equilibrium state with the atmosphere, and all experiments were carried out under thermostatic conditions $\left(25 \pm 0.1^{\circ} \mathrm{C}\right)$.

\subsection{Thermal Spraying Experiments}

Grit blasting was performed using the HVAF-M3 spray gun (Uniquecoat M3 ${ }^{\mathrm{TM}}$ ), the same as for spraying, using a standard hardware configuration i.e., a long nozzle, a large combustion chamber, a short axial powder injector, utilizing DURALUM White F220 alumina grit (mesh 220), and propane as combustion gas. A number of spray parameter sets were initially employed and tested to reach the final optimized process parameters in term of density, Table 2. All coatings were sprayed with the samples rotating, while the HVAF torch was kept fixed. The total thickness of the coatings was in this way controlled through the number of sample rotations. Six different sets of Fe- and Co-based coatings were produced, Table 3. The experiments enabled a comparative study of the corrosion protection between the Fe- and Co-based coatings as well as an evaluation of the effect of different alloying elements, coating thicknesses, and in-flight particle temperatures on corrosion performance. A simultaneous measurement of temperature was achieved via a two-color pyrometer (IR2 SUPERMETER ${ }^{\circledR}$ ultra high performance two-color ratio fiber optic infrared temperature measurement).

Table 2. High velocity air fuel (HVAF) process parameters used in this study.

\begin{tabular}{cc}
\hline Parameter & Value \\
\hline Nozzle & $4 \mathrm{~L} 4$ \\
Spray distance $(\mathrm{mm})$ & 350 \\
Gun traverse velocity $(\mathrm{m} / \mathrm{min})$ & 100 \\
Powder feed rate $(\mathrm{g} / \mathrm{min})$ & 50 \\
Nitrogen carrier gas flow $(\mathrm{L} / \mathrm{min})$ & 60 \\
Air pressure $(\mathrm{MPa})$ & 0.80 \\
Fuel 1 pressure-Propane $(\mathrm{MPa})$ & 0.7 \\
Fuel 2 pressure-Propane $(\mathrm{MPa})$ & 0.7 \\
\hline
\end{tabular}

Table 3. Various types of coatings produced in this study.

\begin{tabular}{cccc}
\hline Coding & Powder Used & In-Flight Particle Temperature $\left({ }^{\circ} \mathrm{C}\right)$ & Thickness * \\
\hline $\mathrm{FeCrNiC} 1$ & Fe-based powder 1 & 1515 & Low \\
$\mathrm{FeCrNiC2}$ & Fe-based powder 1 & 1515 & High \\
$\mathrm{FeCrNiC} 3$ & Fe-based powder 1 & 1400 & High \\
$\mathrm{FeCrNi}$ & Fe-based powder 2 & 1400 & High \\
$\mathrm{CoCrC1}$ & Co-based powder 3 & 1400 & Low \\
$\mathrm{CoCrC2}$ & Co-based powder 3 & 1400 & High \\
\hline \multicolumn{5}{c}{}
\end{tabular}

* The exact values of thickness are given in Table 4 . 


\subsection{Porosity, Microhardness, and Surface Roughness Measurements}

Image analysis was used to measure the porosity content in the coatings by converting the microstructure images of the coatings into binary images. The software ImageJ [38] was utilized. Surface roughness was measured by a stylus based profilometer (Surftest 301, Mitutoyo, Kanagawa, Japan). Micro-hardness measurements were carried out on polished cross sections according to ASTM E384-10 with a Vickers indenter load of $300 \mathrm{~g}$ and a dwell time of $15 \mathrm{~s}$ using a Microhardness Tester (HMV-2, Shimadzu, Columbia, SC, USA).

\subsection{Corrosion Tests}

\subsubsection{OCP (Open-Circuit Potential)}

The corrosion behavior of the sprayed coatings was studied with OCP, potentiodynamic polarization and EIS. As-sprayed coatings without any further treatment such as polishing were used in order to keep the initial surface roughness and possible defects in the top layer of the coating. OCP measurements were carried out by gluing a plastic tube $(\varphi=20 \mathrm{~mm})$ to the coating surface. An amount of $20 \mathrm{~mL}$ of a $3.5 \mathrm{wt} \% \mathrm{NaCl}$ solution was poured into the tube. The OCP was measured up to $24 \mathrm{~h}$ of immersion.

\subsubsection{Potentiodynamic Polarization and EIS Measurements}

Polarization and EIS evaluations were carried out in a conventional three-electrode cell with a counter electrode of platinum foil, an as-sprayed coating as the working electrode (WE) and a reference electrode of saturated calomel electrode (SCE). The surface area of the coatings exposed to the electrolyte was $0.2 \mathrm{~cm}^{2}$. Before each electrochemical measurement, the samples were immersed in the electrolyte at the open-circuit potential for $1 \mathrm{~h}$ which was adequate to acquire a steady state. Polarization curves were generated by scanning the potential range that varied from -250 to $+2000 \mathrm{mV}$ (vs. OCP) at a scanning rate of $1.0 \mathrm{mV} / \mathrm{s}$, using a computer-controlled potentiostat/galvanostat (IVIUMSTAT). The Zview program was used for calculations of anodic $\left(\beta_{a}\right)$ and cathodic $\left(\beta_{c}\right)$ Tafel constants required for polarization resistance calculations. The polarization resistance $\left(R_{p}\right)$ of coatings was calculated by using the Stern-Geary Equation (1) [39]:

$$
R_{p}=\frac{\mathrm{d} E}{\mathrm{~d} i}=\frac{1}{i_{\text {corr }}} \frac{\beta_{a} \beta_{c}}{2.303\left(\beta_{a}+\beta_{c}\right)}
$$

where $i_{c o r r}$ is the corrosion current density, $\beta_{a}$ and $\beta_{c}$ are the slope of anodic and cathodic Tafel lines respectively.

EIS studies were also performed using IVIUMSTAT with an AC amplitude of sinusoidal deviation of $\pm 10 \mathrm{mV}$ and measurement frequency between 10 and $100 \mathrm{kHz}$ around the OCP measured for $30 \mathrm{~s}$ before the EIS measurement. The computer system was equipped with an IVIUMSTAT software analyzer to record EIS data and the Zview program to determine the numerical value of the parameters of the suggested electric circuit model. Fresh sample and fresh solution were used for each exposure. For each experimental condition, two to three measurements were done to ensure the reproducibility and reliability of the data.

\subsection{Coating Characterization}

Cross-sections of the coating systems were metalographically prepared for microstructure analysis. The morphology of the specimens was characterized using a QUANTA 200 FEG scanning electron microscope (SEM) and X-ray energy dispersive spectroscopy (EDS). The phases present in the coatings before and after the corrosion tests were identified by X-ray diffraction (XRD) utilizing a Siemens D500 X-ray Diffractometer with $\mathrm{Cu} \mathrm{K}_{\alpha}$ radiation $(\lambda=0.154 \mathrm{~nm})$ operating with the diffraction angle $(2 \theta)$ varied between $25^{\circ}$ and $85^{\circ}$. 


\section{Results}

\subsection{Characterizing the Coatings}

Micrographs of the as-sprayed Fe- and Co-based coatings are shown in Figure 2a-f. All coatings showed a lamellar structure with elongated impacted splats parallel to the substrate surface. This lamellar structure was most significant in the FeNiCr coating, which implies that the low-alloyed Fe-based powder was better melted during spraying.

Porosity has been shown as an important parameter that can significantly influence the corrosion performance of thermal spray coatings $[8,19,40,41]$. The pores permit the electrolyte to penetrate and attack the substrate chemically [42]. The porosity level was low for the FeCrNi, reaching a maximum of $0.1 \%$, while the values were measured at $2.6 \%, 2.2 \%$, and $4.7 \%$ for the FeCrNiC coatings 1,2 , and 3 respectively. The porosity content in the $\mathrm{CoCrC} 1$ and the $\mathrm{CoCrC} 2$ coatings were measured at $2.9 \%$ and $2.2 \%$ respectively. Increasing the in-flight particle temperature from $1400^{\circ} \mathrm{C}$ in FeCrNiC3 (Figure $2 \mathrm{c}$ ) to $1515^{\circ} \mathrm{C}$ in FeCrNiC2 resulted in a denser microstructure, as in Figure $2 \mathrm{a}, \mathrm{b}$.
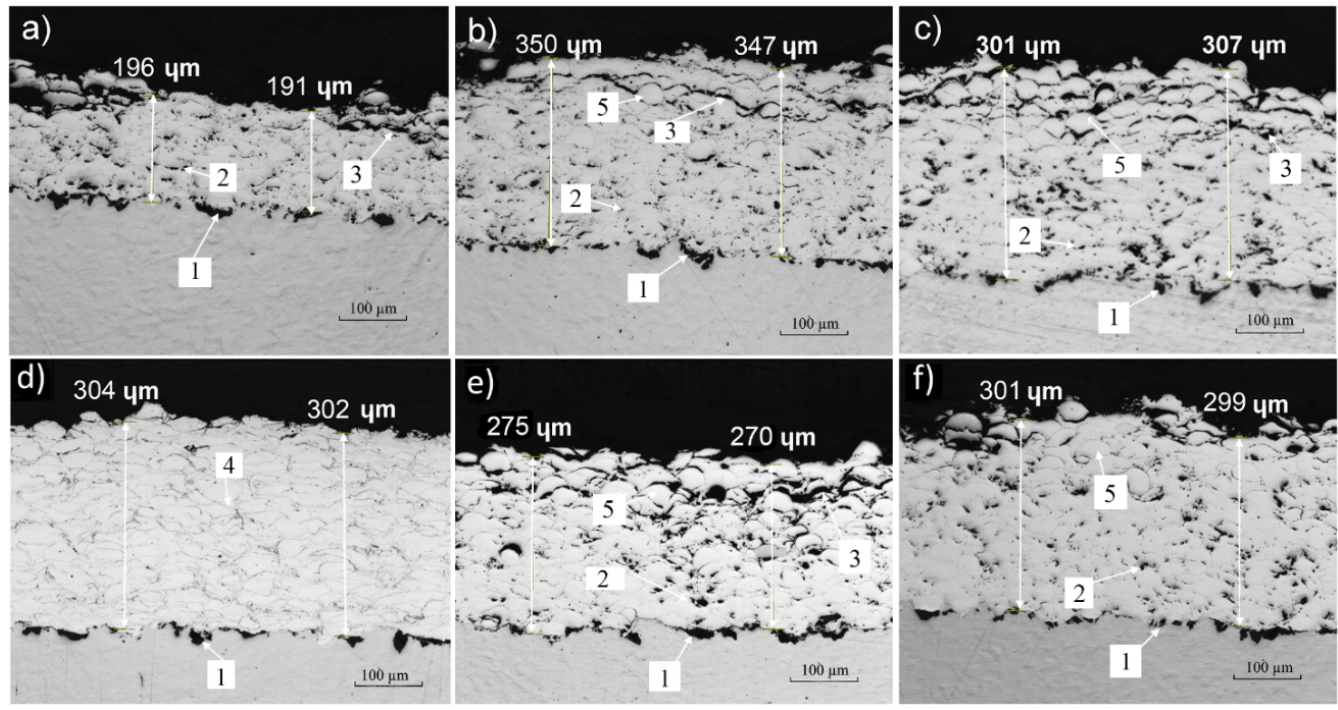

Figure 2. OM micrographs of as-sprayed coatings, (a) FeCrNiC1; (b) FeCrNiC2; (c) FeCrNiC3; (d) $\mathrm{FeCrNi}$; (e) $\mathrm{CoCrC} 1$; and (f) $\mathrm{CoCrC2}$, (features of the coatings: 1: Embedded grit blasting $\mathrm{Al}_{2} \mathrm{O}_{3}$ particles; 2: Pores; 3: Cracks; 4: Lamellar structure; 5: Unmelted or semimelted particles).

SEM cross-sectional images of the coatings are shown in Figure 3. All coatings had a fairly porous structure in the near-surface region, however this porosity was expected not to be critical for corrosion resistance, as the pores were shallow and disconnected. The pores were specifically shown to be disconnected in the bottom region of the coating, where the coatings were shown to be well-attached to the substrate. This implied that the corrosive ions would not penetrate deep enough to reach the substrate/coating interface [7]. Furthermore, there could be a trade-off among coating microstructure, feedstock characteristics, and coating properties. The defects e.g., porosity, or oxide might be compensated by the chemical composition of the coating in terms of coating properties (particularly corrosion) by adding some effective elements, e.g., Cr, Mo or Ni.

The measured thickness, surface roughness, and microhardness of the coatings are given in Table 4. The respective value is an average of thirty measurements done on three different samples of each coating.

The surface roughness is important in terms of corrosion protection, as a lower surface roughness leads to a lower surface area exposed to the corrosive environment, which can result in less susceptibility to both general and localized corrosion [43]. The FeCrNiC coating had the highest 
roughness $3(8.9 \mu \mathrm{m})$ which should be compared to the FeCrNi coating $(5.3 \mu \mathrm{m})$, which had the smoothest surface. It should be noted that the coating roughness can be decreased in the HVAF by increasing both particle velocity and flame temperature but no such optimization was performed [24].
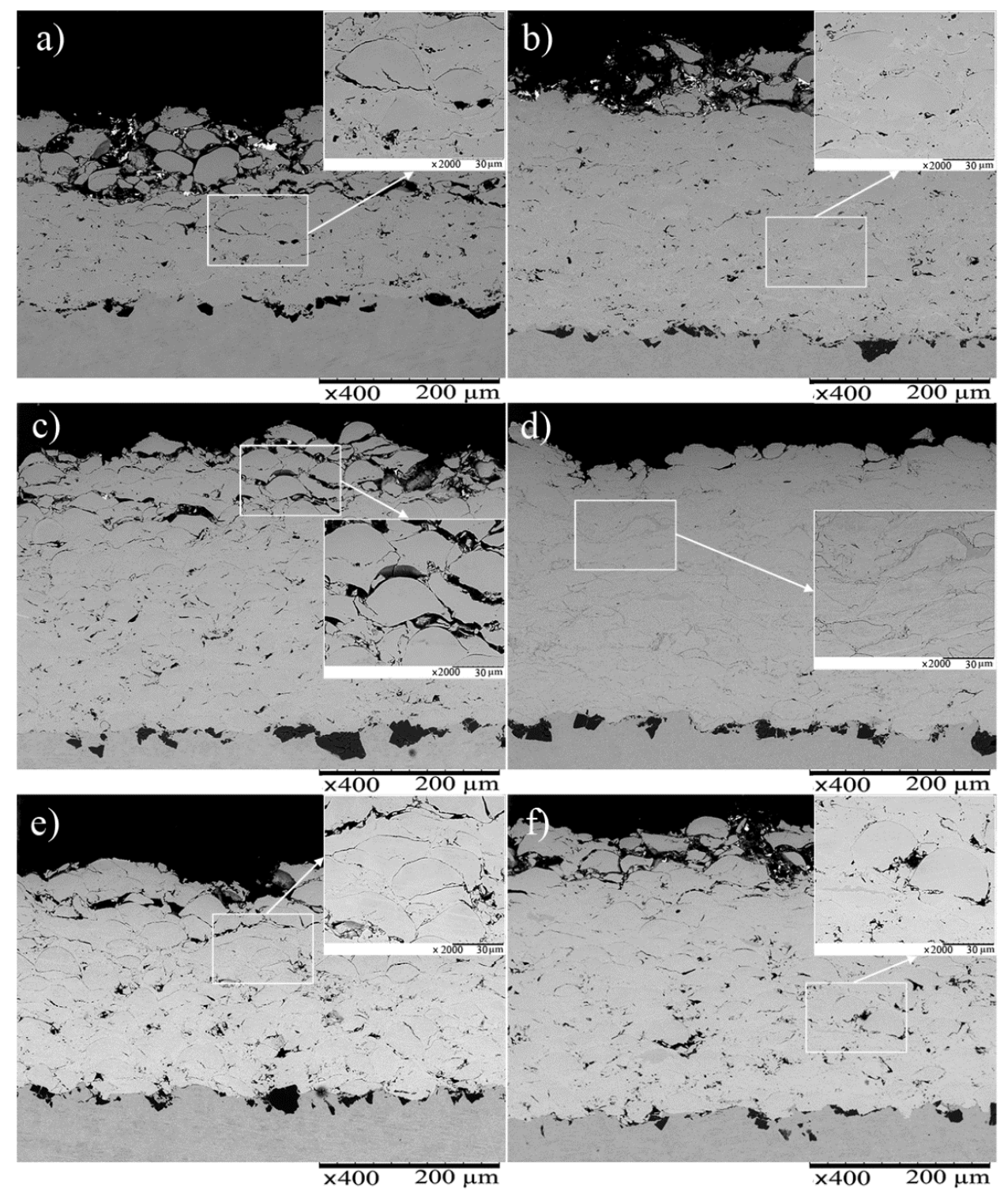

Figure 3. Cross sectional SEM micrographs of as-sprayed coatings. (a) FeCrNiC1; (b) FeCrNiC2; (c) FeCrNiC3; (d) FeCrNi; (e) CoCrC1; and (f) CoCrC2.

Table 4. Coating thicknesses, surface roughness, and microhardness.

\begin{tabular}{cccc}
\hline Coding & Thickness $(\boldsymbol{\mu m})$ & Roughness $(\boldsymbol{\mu m})$ & Microhardness $\left(\mathbf{H V}_{\mathbf{0 . 3}}\right)$ \\
\hline FeCrNiC1 & $183 \pm 10$ & $6 \pm 0.6$ & $632 \pm 20$ \\
$\mathrm{FeCrNiC2}$ & $378 \pm 8$ & $5 \pm 0.8$ & $658 \pm 26$ \\
$\mathrm{FeCrNiC} 3$ & $304 \pm 3$ & $9 \pm 0.3$ & $611 \pm 15$ \\
$\mathrm{FeCrNi}$ & $308 \pm 8$ & $5 \pm 0.5$ & $350 \pm 10$ \\
$\mathrm{CoCrC} 1$ & $272 \pm 13$ & $8 \pm 0.6$ & $863 \pm 19$ \\
$\mathrm{CoCrC} 2$ & $315 \pm 5$ & $7 \pm 0.3$ & $833 \pm 15$ \\
\hline
\end{tabular}

* Error bars $( \pm)$ represent standard deviation associated with average values of 30 measurements for each coating. 
For the maximum protection of the substrate, thermal spray coatings have to be dense and defect-free in order to prevent the corrosive ions penetrating through defects (connected pores and cracks) and reach the substrate [44]. In this case, localized corrosion such as pitting and crevice may occur autocatalytically [45]. Fe-based coatings free of defects could not be achieved probably because of the inherent characteristics of the thermal spraying process as it is shown in Figure 3. For instance, the $\mathrm{Cr}$ content of the alloy might rapidly oxidize during spraying (due to a great susceptibility of $\mathrm{Cr}$ to oxidation). Formation of chromium oxides within the spraying consumes $\mathrm{Cr}$ which could be used later in corrosion prevention by formation of the surface passive layer. Therefore, Cr-depletion zones are formed due to the lack of sufficient available $\mathrm{Cr}$ which finally leads the coating to be corroded [46]. Thus, increasing the level of accessible $\mathrm{Cr}$ in the coating could improve the corrosion behavior. Altering the thickness of the coating is also reported as a way that can reduce the rate of corrosive ion penetration through defects [24]. Thinner coating permits the electrolyte to meet the substrate through the coating defect, as it is not sufficiently thick to protect the substrate, unless the chemical composition of the coating (presence of alloying elements such as $\mathrm{Cr}$ ) compromises the detrimental effect of the defects.

The presence of carbon in the coatings that contains $\mathrm{Cr}$ is probably one reason for the higher hardness values in Co-based coatings due to the formation of carbides, particularly $\mathrm{Cr}_{2} \mathrm{C}_{3}$. Another reason for the higher hardness values of these two coatings could be attributed to cobalt itself, since $\mathrm{Co}$ is inherently harder than $\mathrm{Fe}$, and due to inclusions of cobalt oxides, a finer lamellar microstructure, and the presence of carbides, mainly $\mathrm{Cr}_{2} \mathrm{C}_{3}$, because of the presence of $\mathrm{C}$ and $\mathrm{Cr}$ in the feedstock Co-based powder. It is well understood that an increase in the level of coating porosity decreases the coating hardness [47]. However, the $\mathrm{CoCrC1}$ coating shows a higher hardness value than the $\mathrm{CoCrC}_{2}$ coating, while the former presents a higher pore content than the latter. As the hardness measurement was performed in the area where the coatings showed dense and compact microstructures, the hardness values represent the hardness of the particles impacting the substrate, regardless of the level of pores around them.

The fairly high scatter in the microhardness values, might be due to the presence of heterogeneities in the composition of the coatings. This scatter enhances the coating sensitivity to some certain types of corrosion, particularly microgalvanic corrosion.

The phase identification of XRD patterns (Figure 4) showed the presence of an austenitic $(\gamma)$ matrix in the Fe-based coating, Co phase in Co-based coatings. A slight martensitic phase was also detectable which might be due to the high cooling rate during particle solidification. No $\sigma-\mathrm{FeCr}$ phase was observed which is susceptible to be formed at low particle cooling rate. A minor presence of $\mathrm{Cr}_{2} \mathrm{O}_{3}$ is indicated due to the increase of the low intensity peak at $38^{\circ}$. The XRD analysis was unable to identify any other presence of oxides, which might be due to the overall high roughness of the coatings [4].

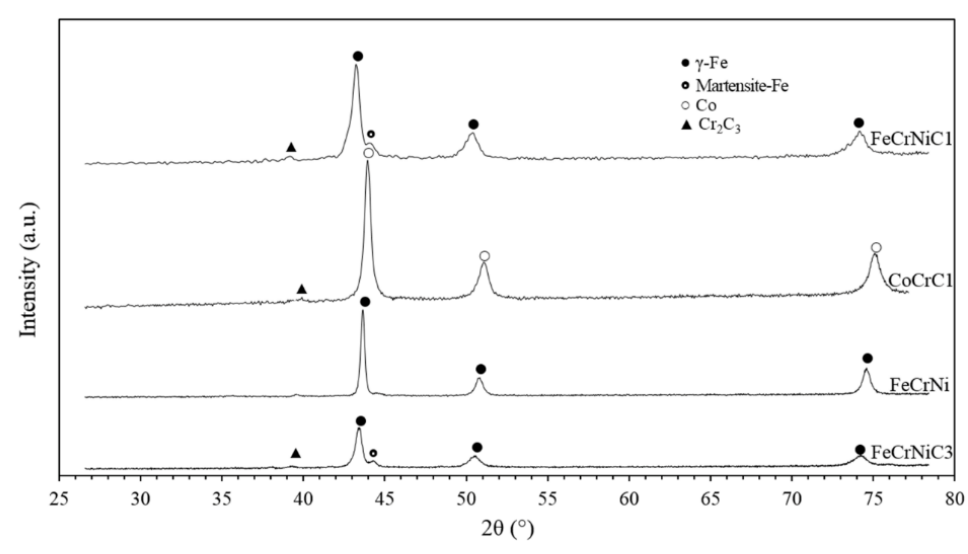

Figure 4. X-ray diffraction (XRD) patterns of as-sprayed coatings. 


\section{2. $O C P$}

The penetration of the corrosive species of the electrolyte along the coating thickness towards the substrate was evaluated by OCP measurements at up to $24 \mathrm{~h}$ of immersion (Figure 5). Higher potential values were measured for the Fe-based coatings (FeCrNi and FeCrNiC1) than both Co-based coatings. This implies that the Fe-based coatings have a better barrier effect compared to both Co-based coatings. The reason for this difference is probably attributed to the lack of interconnected porosity in the Fe-based coatings.

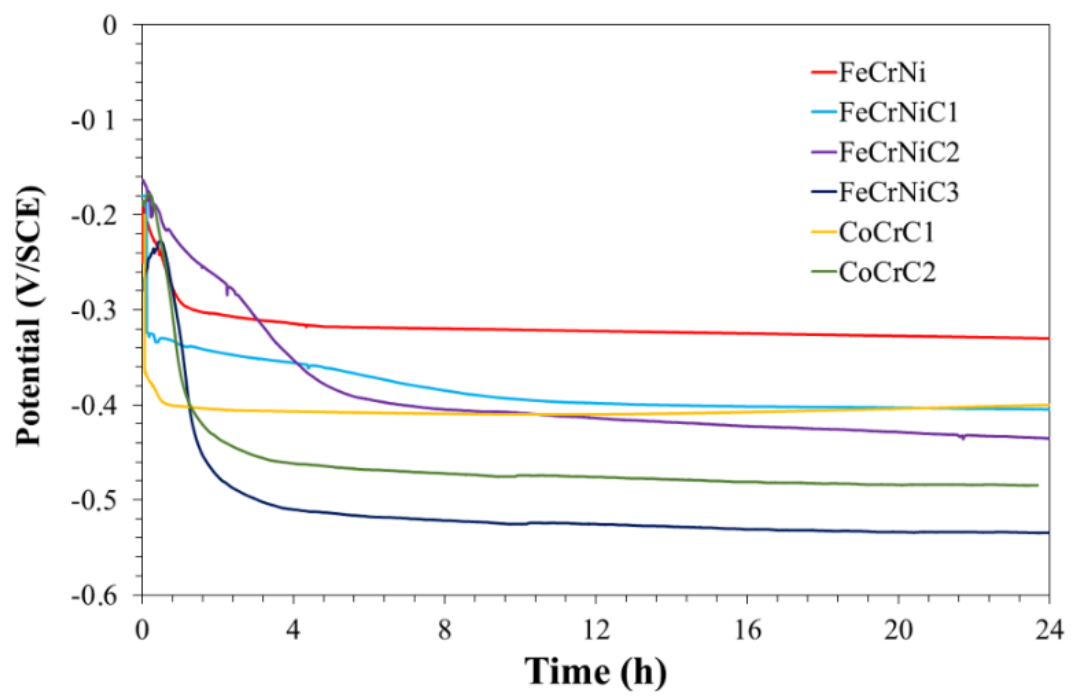

Figure 5. Open-circuit potential (OCP) plots for the five coatings $\left(24 \mathrm{~h}\right.$ in $3.5 \mathrm{wt} \% \mathrm{NaCl}$, at $\left.25^{\circ} \mathrm{C}\right)$.

At the very early stage of the test, both Co-based coatings showed an initial low potential, which slowly increased and was later followed by a decrease over time. A potential drop at the beginning of the test was also detected for most of the coatings. The initial potential decrease can be due to; (1) the variation in the surface activity primarily due to the electrolyte penetration along the coating; and (2) the dissolution of the initial oxide layer, which was naturally formed, after immersion into the electrolyte. The decrease of potential after the first hours, confirmed the penetration of the corrosive ions through open porosity or localized defects. However, after such a drop, the potential became steady probably due to clogging of open-pores rather than the passivation of the coating. The frequent potential oscillations imply a susceptibility of the coatings to a localized corrosion such as pitting.

\subsection{Potentiodynamic Measurements}

Potentiodynamic polarization plots of various coatings immersed in $3.5 \mathrm{wt} \% \mathrm{NaCl}$ at $25^{\circ} \mathrm{C}$ are presented in Figure 6 to illustrate the overall kinetics of the corrosion process. Electrochemical parameters including the corrosion potential $\left(E_{\text {corr }}\right)$, corrosion current density $\left(i_{\text {corr }}\right)$, anodic $\left(\beta_{a}\right)$ and cathodic $\left(\beta_{c}\right)$ Tafel slopes, and polarization resistance $\left(R_{p}\right)$, derived from the potentiodynamic polarization plots in Figure 6, are given in Table 5.

Apart from the FeCrNiC1 coating which had a potential of $-0.25 \mathrm{~V}$, the $E_{\text {corr }}$ of the other coatings varied from -0.31 to $-0.38 \mathrm{~V}$, thus showing negligible differences between those samples thermodynamically. The $i_{\text {corr }}$ varied from 0.9 to $9.4 \mu \mathrm{Acm}^{-2}$. The FeCrNi coating had a high passive current density $\left(i_{\text {pass }}\right)$ combined with a narrow passive region and it even underwent active dissolution at the low potential without any visible passivation.

The lowest corrosion current density was observed for the FeCrNiC1 coating $\left(0.9 \mu \mathrm{Acm}^{-2}\right)$, which is due to the formation of a stable and protective superficial layer. It was not possible to find a direct 
correlation between coating defects and $i_{\text {corr }}$. The reason is probably the elemental composition in addition to that of the defects which can play a significant role in the corrosion process.

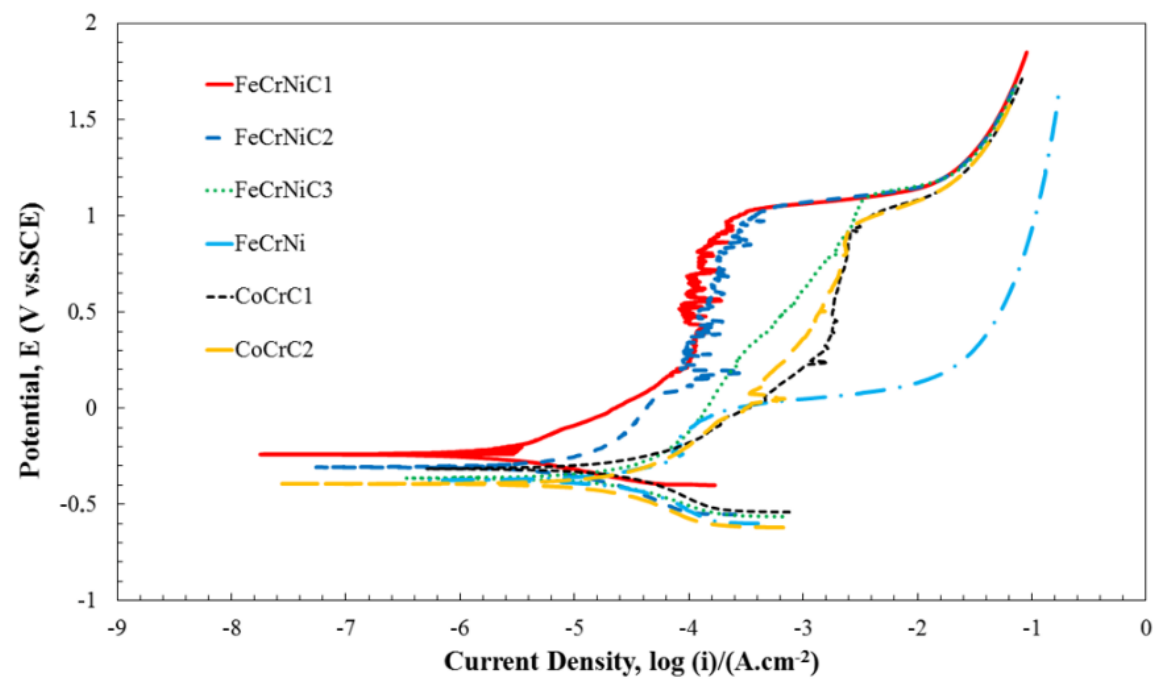

Figure 6. Potentiodynamic polarization plots of the Fe- and Co-based coatings immersed in $3.5 \% \mathrm{NaCl}$, at $25^{\circ} \mathrm{C}$.

Table 5. Electrochemical values of the coated and uncoated steel substrate, immersed in $3.5 \% \mathrm{NaCl}$, at $25^{\circ} \mathrm{C}$.

\begin{tabular}{|c|c|c|c|c|c|}
\hline Coding & $i_{\text {corr }}\left(\mu \mathrm{A} \mathrm{cm}^{-2}\right)$ & $E_{\text {corr }}(\mathrm{V}$ vs. SCE) & $\beta_{\mathrm{a}}\left(\mathrm{V} \mathrm{dec}^{-1}\right)$ & $-\beta_{\mathrm{c}}(\mathrm{V} \mathrm{dec}-1)$ & $R_{\mathrm{p}}\left(\mathrm{k} \Omega \mathrm{cm}^{2}\right)$ \\
\hline $\mathrm{FeCrNiC1}$ & $0.9 \pm 0.1$ & $-0.25 \pm 0.02$ & $0.26 \pm 0.03$ & $0.18 \pm 0.03$ & $43.9 \pm 0.5$ \\
\hline $\mathrm{FeCrNiC} 2$ & $1.9 \pm 0.2$ & $-0.31 \pm 0.03$ & $0.21 \pm 0.02$ & $0.13 \pm 0.02$ & $18.3 \pm 0.2$ \\
\hline $\mathrm{FeCrNiC3}$ & $9.4 \pm 1.3$ & $-0.36 \pm 0.03$ & $0.24 \pm 0.03$ & $0.16 \pm 0.02$ & $4.4 \pm 0.1$ \\
\hline $\mathrm{FeCrNi}$ & $7.7 \pm 0.6$ & $-0.37 \pm 0.03$ & $0.16 \pm 0.01$ & $0.09 \pm 0.01$ & $3.2 \pm 0.1$ \\
\hline $\mathrm{CoCrC} 1$ & $8.1 \pm 0.5$ & $-0.32 \pm 0.03$ & $0.17 \pm 0.01$ & $0.14 \pm 0.02$ & $4.1 \pm 0.2$ \\
\hline $\mathrm{CoCrC} 2$ & $4.7 \pm 0.5$ & $-0.38 \pm 0.04$ & $0.12 \pm 0.01$ & $0.11 \pm 0.02$ & $5.3 \pm 0.3$ \\
\hline
\end{tabular}

The FeCrNiC3 and $\mathrm{CoCrC} 1$ coatings showed a passivation stage at a relatively high $i_{\text {pass }}$. The reason for this behavior might be the structural defects in these coatings including pores and microcracks, Figure 6. The FeCrNi coating showed a similar behavior which might be due in this case to the lamellar structure of this coating. The presence of the lamella boundaries hinders the outward migration of $\mathrm{Cr}$ to reach the top surface of the coating which eventually leads to weak passivation. The FeCrNiC1 and FeCrNiC2 coatings showed an exhibited passivation stage at low $i_{\text {corr }}$ with some tiny fluctuations. The fluctuations imply a continuous process of active solution and passivation. The transpassive potential $\left(E_{\text {trans }}\right)$ of these coatings was about $1.0 \mathrm{~V}$ combined with a broad passive region, which confirmed that these coatings had an ability to prevent localized corrosion. Contrarily, the very limited passive region of the FeCrNi coating illustrated a low ability to hinder localized corrosion. The $E_{\text {corr }}$ value was lower in the Co-based coatings compared to the FeCrNiC coatings, which confirms that these coatings were more active as galvanic couples. The passivation stage of the Co-based coatings occurred at higher $i_{\text {corr }}$ compared to the FeCrNiC coatings, implying a poor ability for the surface passive films to be stable. However, broad passive regions were identified by similarly high $E_{\text {trans }}, 1.0 \mathrm{~V}$, as observed in the FeCrNiC coatings. Thus, the Fe-based coatings, especially FeCrNiC1, seem efficient as a protective barrier with excellent corrosion properties and ability to prevent localized corrosion in aggressive environments.

The high resistance to localized corrosion such as pitting of the high-alloyed Fe-based coatings was considered to be determined by the presence of Cr-rich passive surface films formed on the Fe-based 
coatings, which prevented further attack by the corrosive solution. Moreover, Mo content of the coating could also reduce the possibility of pitting, improving the corrosion resistance and passivating ability. It is well understood that Mo could control the dissolution of $\mathrm{Cr}$ during passivation [40]. FeCrNiC1 and $\mathrm{FeCrNiC} 2$ coatings which contained high amounts of $\mathrm{Cr}$, Mo, and $\mathrm{Ni}$ were observed to have very low $i_{c o r r}$ and, thereby, high resistance to corrosion. This indicates that the corrosion resistance of the Fe-based coatings is sensitive to the microstructure characteristics which were shown to be dependent on the spraying parameters.

It can be hypothesized that "passive-like" stages were produced due to the formation of a thin passive oxide film. However, defects such as pores, oxide inclusions, and interlamellar boundaries led to an interruption in perfect passivity, as these defects act as barriers for diffusion of beneficial elements (such as $\mathrm{Cr}$ ) for passivation $[4,8,24,48,49]$. The initial breakaway of a "passive-like" stage might be connected to the galvanic microcells or selective corrosion along lamellae boundaries, based on a mechanism identical to pitting. The former produces quite low damage; therefore, it can be attributed to lower anodic $i_{\text {corr }}$; instead, the latter inflicts more damage, resulting in higher anodic $i_{\text {corr }}$.

The largest polarization resistance $R_{p}$ was consistently reported for the $\mathrm{FeCrNiC1}$ coating $\left(43.9 \mathrm{k} \Omega \mathrm{cm}^{2}\right)$ due to the coatings low $i_{\text {corr }}$ and quite high $\beta_{a}$ and $\beta_{c}$. Table 5, High $\beta_{a}$ and $\beta_{c}$ lead to lower anodic and cathodic current at the same overpotential during the polarization measurements which consequently results in higher $R_{p}$.

\subsection{EIS (Electrochemical Impedance Spectroscopy)}

EIS is a non-destructive method that relies on a small AC-voltage signal $(20 \mathrm{mV})$, which is applicable for resistance and capacitance studies of the coatings through a fit of the data to a proper circuit model. Nyquist and Bode diagrams of coatings in $3.5 \mathrm{wt} \% \mathrm{NaCl}$ solution is shown in Figure 7a,b. During the exposure, corrosive ions penetrated the defects through the coating before reaching the substrate. Thus, at the beginning of the test, the electrochemical behavior could be associated with the intrinsic properties of the coating.
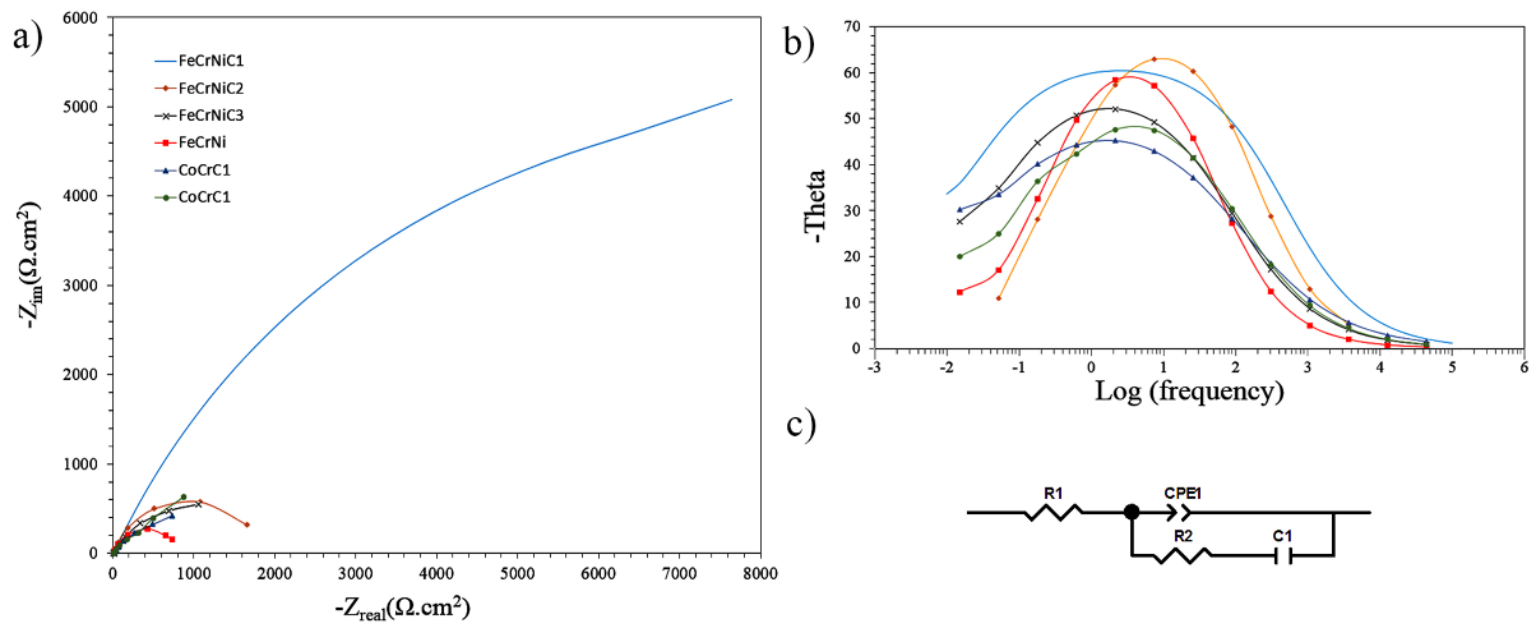

c)

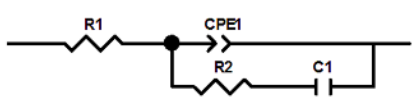

Figure 7. (a) Nyquist; (b) bode diagrams for HVAF coated samples in $3.5 \% \mathrm{NaCl}$, at $25{ }^{\circ} \mathrm{C}$; (c) Equivalent electric circuit for all coatings.

The EIS results show the presence of one capacitive loop for all coatings. The diameter of this capacitance loop can be linked to the corrosion resistance. The fact that only one single time constant was gained might be less likely due to the short exposure time. The electrolyte failed to penetrate through the whole thickness of the coating and thus reaching the coating/substrate interface. Thus, the electrochemical characteristics derived from the EIS measurements could be attributed to the Faradaic process (as a result of charge transfer across the interface) that comprised the coating reactivity [50]. 
The formation of corrosion products showed a pore partial sealing in small pores [51]. However, these corrosion products had poor adherence, which eventually led the electrolyte to penetrate further through the pores.

Consequently, a simple equivalent circuit to describe the electrochemical behavior of coatings was suggested, as shown in Figure 7c. The equivalent circuits included the solution resistance $\left(R_{s}\right)$, charge transfer resistance in the coating/solution interface $\left(R_{c t}\right)$, and coating double-layer capacitance $\left(C_{d l}\right)$ described by a constant phase element $(C P E)$.

The corrosion parameters derived from the equivalent electric circuit are given in Table 6. $R_{c t}$ describes the ability of the coating to inhibit ion transfer at the solution/coating interface. It can be observed that $R_{c t}$ decreased with the increase of defects within the coating and most likely due to the dissolution of oxides because of chloride ion adsorption and chloride attack of the passive film. The higher $R_{c t}$ confirmed the lower exposed coating/electrolyte interface and therefore lower coating open porosity and accordingly less corrosion of the coating. This confirms a better corrosion resistance of the FeCrNiC1 coating compared to both Co-based coatings. The high-alloyed Fe-based coating $(\mathrm{FeCrNiC} 1)$ showed a better corrosion protection performance compared to the low-alloyed Fe-based (FeCrNi) in the $3.5 \mathrm{wt} \% \mathrm{NaCl}$ solution.

Table 6. Electrochemical parameters gained from electrochemical impedance spectroscopy (EIS) spectra of HVAF coated samples.

\begin{tabular}{|c|c|c|c|c|c|}
\hline Coating & $R_{S}\left(\Omega \cdot \mathrm{cm}^{2}\right)$ & $R_{c t}\left(\mathrm{k} \Omega \cdot \mathrm{cm}^{2}\right)$ & CРЕ-T $\left(\mu \mathrm{F} \cdot \mathrm{cm}^{-2}\right)$ & $n$ & $C_{d l}\left(\mu \mathrm{F} \cdot \mathrm{cm}^{-2}\right)$ \\
\hline $\mathrm{FeCrNiC1}$ & 9.9 & 20.1 & 0.05 & 0.79 & 120 \\
\hline $\mathrm{FeCrNiC2}$ & 10.2 & 6.8 & 0.17 & 0.80 & 4000 \\
\hline $\mathrm{FeCrNiC3}$ & 9.9 & 4.4 & 0.07 & 0.78 & 5020 \\
\hline $\mathrm{FeCrNi}$ & 10.0 & 0.8 & 0.05 & 0.79 & 925 \\
\hline $\mathrm{CoCrC1}$ & 10.0 & 2.1 & 0.08 & 0.76 & 5115 \\
\hline $\mathrm{CoCrC} 2$ & 10.1 & 2.8 & 0.08 & 0.75 & 5040 \\
\hline
\end{tabular}

CPE is generally employed to model the behavior of double layers in real electrochemical processes [52]. CPE means the double layer capacitance at the solution/coating interface which includes the interfaces between the top surface of the coating and the solution and also the surface of defects with the solution. The measured value of CPE (Table 6) suggests that the porosity increased during the immersion, accordingly, due to the penetration of the solution. The "plugging effect" resulting from the accumulation of corrosion products in defects might be a reason for the increase in CPE $[2,28]$.

The time constants $n$ of all the coatings attributed to the charge transfer reaction were relatively similar, confirming that the same electrochemical mechanism occurred. By definition, the capacitance has a direct relationship to the electrical permittivity of the material and to the total exposed surface area as well as an inverse relationship with the distance between the two conductive plates [53]. As the electrical permittivity of the $3.5 \mathrm{wt} \% \mathrm{NaCl}$ solution and the distance (the thickness of the electrical double layer formed on the coating surface) were fixed, a decrease of the double layer capacitance might be associated with a lower electrolyte penetration (i.e., lower overall area) and thus, lower open porosity [24].

\subsection{Surface Morphology}

Figures 8 and 9 show the morphology of the surface coatings after $24 \mathrm{~h}$ immersion in the OCP test for the coating of each group that experienced the highest corrosion ( $\mathrm{FeNiCrC}_{3}$ and $\left.\mathrm{CoCrC} 1\right)$ to clarify the corrosion mechanism of the coating.

The corrosion mechanism was similar to crevice or pitting corrosion and the pores acted as blocked cells, which had catalytic influences on the corrosion reactions, as the diffusion of $\mathrm{O}_{2}$ molecules into these defects was much slower than that of small $\mathrm{Cl}^{-}$. Additionally, the oxygen depletion caused a fast 
decline of the electrolyte $\mathrm{pH}$ in the crevice [7]. The $\mathrm{Cl}^{-}$penetrating into the crevices favors hydrolysis reactions, which further decreases the electrolyte $\mathrm{pH}$. Over time, the inner corrosion products of $\mathrm{Fe}^{2+}$ or $\mathrm{Co}^{2+}$ migrated to the coating surface, where the hydroxide was generated.
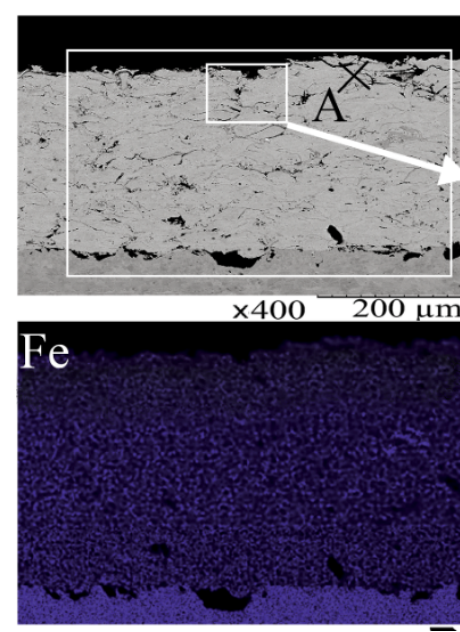
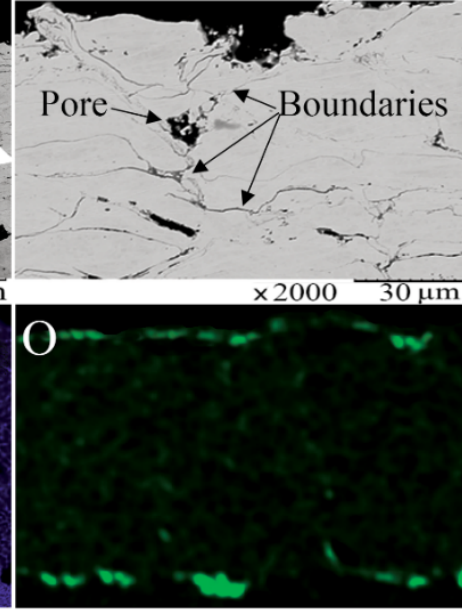
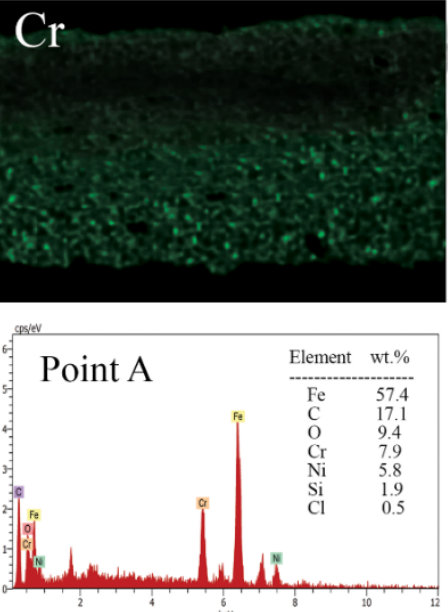

Figure 8. Microstructure, elemental mapping and point $\mathrm{X}$-ray energy dispersive spectroscopy (EDS) analysis of the corroded $\mathrm{FeNiCrC}_{3}$ coating after $24 \mathrm{~h} \mathrm{OCP}$ test, at $25^{\circ} \mathrm{C}$.
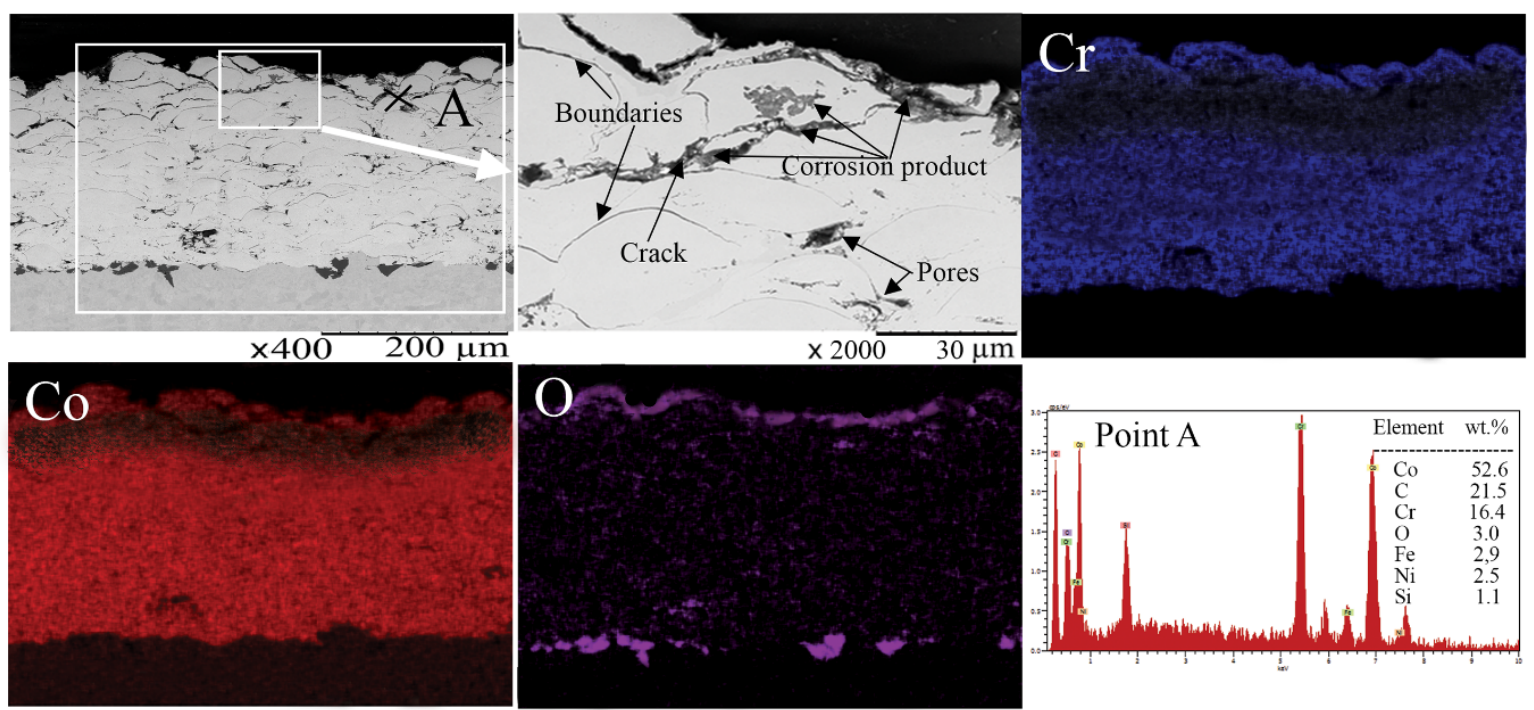

Figure 9. Microstructure, elemental mapping and point EDS analysis of the corroded $\mathrm{CoCrC} 1$ coating after $24 \mathrm{~h} \mathrm{OCP}$ test, at $25^{\circ} \mathrm{C}$.

\section{Conclusions}

The corrosion behavior of HVAF thermally sprayed Fe- and Co-based coatings was studied using electrochemical measurements. The major conclusions taken from the work can be summarized as follows:

(1) The high-alloyed Fe-based coating showed the best corrosion protection performance protecting the underlying substrate better than both the low-alloyed Fe-based and the Co-based coatings.

(2) The corrosion resistance of the Fe-based coatings was significantly improved by adding Cr.

(3) The coating thickness was shown to be an important parameter affecting the diffusion of the corrosive electrolyte. Thin Co-based coating permitted the corrosive ions to diffuse, while thin Fe-based coating showed better corrosion behavior compared to thick Fe-based coatings. 
(4) Increasing the average in-flight particle temperature from $1400{ }^{\circ} \mathrm{C}$ to $1500{ }^{\circ} \mathrm{C}$ resulted in a denser coating, which seemed to improve the corrosion resistance of the Fe based coatings.

(5) Pores, cracks, and interlamellar boundaries were shown as preferred sites for corrosion nucleation and growths.

(6) The high-alloyed Fe-based coatings showed, in general, the best corrosion performance and can thus be recommended as a potential alternative to Co-based coatings.

Acknowledgments: The authors wish to thank Stefan Björklund and Senad Dizdar for their advice, and experimental assistance in this study.

Author Contributions: Esmaeil Sadeghimeresht, Nicolaie Markocsan and Per Nylén conceived designed the experiments; Esmaeil Sadeghimeresht performed the experiments; Esmaeil Sadeghimeresht analyzed the data; Esmaeil Sadeghimeresht, Nicolaie Markocsan and Per Nylén contributed reagents/materials/analysis tools; Esmaeil Sadeghimeresht wrote the paper.

Conflicts of Interest: The authors declare no conflict of interest.

\section{References}

1. Liu, X.Q.; Zheng, Y.G.; Chang, X.C.; Hou, W.L.; Wang, J.Q.; Tang, Z.; Burgess, A. Microstructure and properties of Fe-based amorphous metallic coating produced by high velocity axial plasma spraying. J. Alloys Compd. 2009, 484, 300-307. [CrossRef]

2. Guo, R.Q.; Zhang, C.; Yang, Y.; Peng, Y.; Liu, L. Corrosion and wear resistance of a Fe-based amorphous coating in underground environment. Intermetallics 2012, 30, 94-99. [CrossRef]

3. Lu, W.; Wu, Y.; Zhang, J.; Hong, S.; Zhang, J.; Li, G. Microstructure and Corrosion Resistance of Plasma Sprayed Fe-Based Alloy Coating as an Alternative to Hard Chromium. J. Therm. Spray Technol. 2010, 20, 1063-1070. [CrossRef]

4. Brandolt, C.S.; Ortega Vega, M.R.; Menezes, T.L.; Schroeder, R.M.; Malfatti, C.F. Corrosion behavior of nickel and cobalt coatings obtained by high-velocity oxy-fuel (HVOF) thermal spraying on API 5CT P110 steel. Mater. Corros. 2015. [CrossRef]

5. Liu, W.H.; Shieu, F.S.; Hsiao, W.T. Enhancement of wear and corrosion resistance of iron-based hard coatings deposited by high-velocity oxygen fuel (HVOF) thermal spraying. Surf. Coat. Technol. 2014, 249, 24-41. [CrossRef]

6. Gao, Y.; Xiong, J.; Gong, D.; Li, J.; Ding, M. Improvement of solar absorbing property of Ni-Mo based thermal spray coatings by laser surface treatment. Vacuum 2015, 121, 64-69. [CrossRef]

7. Picas, J.A.; Rupérez, E.; Punset, M.; Forn, A. Influence of HVOF spraying parameters on the corrosion resistance of WC-CoCr coatings in strong acidic environment. Surf. Coat. Technol. 2013, 225, 47-57. [CrossRef]

8. Sá Brito, V.R.S.; Bastos, I.N.; Costa, H.R.M. Corrosion resistance and characterization of metallic coatings deposited by thermal spray on carbon steel. Mater. Des. 2012, 41, 282-288. [CrossRef]

9. Berger, L.M. Application of hard metals as thermal spray coatings. Int. J. Refract. Met. Hard Mater. 2015, 49, 350-364. [CrossRef]

10. Milanti, A.; Koivuluoto, H.; Vuoristo, P. Influence of the Spray Gun Type on Microstructure and Properties of HVAF Sprayed Fe-Based Corrosion Resistant Coatings. J. Therm. Spray Technol. 2015, 24, 1312-1322. [CrossRef]

11. Zhou, Z.; Wang, L.; Wang, F.; Liu, Y. Formation and corrosion behavior of Fe-based amorphous metallic coatings prepared by detonation gun spraying. Trans. Nonferrous Met. Soc. China 2009, 19, 634-638. [CrossRef]

12. Bolelli, G.; Bonferroni, B.; Laurila, J.; Lusvarghi, L.; Milanti, A.; Niemi, K.; Vuoristo, P. Micromechanical properties and sliding wear behaviour of HVOF-sprayed Fe-based alloy coatings. Wear 2012, 276, $29-47$. [CrossRef]

13. Zhang, C.; Liu, L.; Chan, K.C.; Chen, Q.; Tang, C.Y. Wear behavior of HVOF-sprayed Fe-based amorphous coatings. Intermetallics 2012, 29, 80-85. [CrossRef]

14. Farmer, J.; Choi, J.S.; Saw, C.; Haslam, J.; Day, D.; Hailey, P.; Lian, T.; Rebak, R.; Perepezko, J.; Payer, J.; et al. Iron-Based Amorphous Metals: High-Performance Corrosion-Resistant Material Development. Metall. Mater. Trans. A 2009, 40, 1289-1305. 
15. Maddala, D.R.; Hebert, R.J. Sliding wear behavior of Fe50-xCr15Mo14C15B6Erx (x=0, 1, 2 at \%) bulk metallic glass. Wear 2012, 294, 246-256. [CrossRef]

16. Guo, W.; Wu, Y.; Zhang, J.; Hong, S.; Li, G.; Ying, G.; Guo, J.; Qin, Y. Fabrication and Characterization of Thermal-Sprayed Fe-Based Amorphous/Nanocrystalline Composite Coatings: An Overview. J. Therm. Spray Technol. 2014, 23, 1157-1180. [CrossRef]

17. Qiu, M.M.; Wang, H.; Wu, X.; Tang, H.Q.; Su, G.C. Study on the Corrosion Resistance of High Boron Iron-Based Alloy. Appl. Mech. Mater. 2012, 268, 326-329. [CrossRef]

18. Pokhmurskii, V.; Student, M.; Gvozdeckii, V.; Stypnutskyy, T.; Student, O.; Wielage, B.; Pokhmurska, H. Arc-Sprayed Iron-Based Coatings for Erosion-Corrosion Protection of Boiler Tubes at Elevated Temperatures. J. Therm. Spray Technol. 2013, 22, 808-819. [CrossRef]

19. Zhang, S.D.; Zhang, W.L.; Wang, S.G.; Gu, X.J.; Wang, J.Q. Characterisation of three-dimensional porosity in an Fe-based amorphous coating and its correlation with corrosion behaviour. Corros. Sci. 2015, 93, 211-221. [CrossRef]

20. Katakam, S.; Hwang, J.Y.; Paital, S.; Banerjee, R.; Vora, H.; Dahotre, N.B. In Situ Laser Synthesis of Fe-Based Amorphous Matrix Composite Coating on Structural Steel. Metall. Mater. Trans. A 2012, 43, 4957-4966. [CrossRef]

21. Lampke, T.; Wielage, B.; Pokhmurska, H.; Rupprecht, C.; Schuberth, S.; Drehmann, R.; Schreiber, F. Development of particle-reinforced nanostructured iron-based composite alloys for thermal spraying. Surf. Coat. Technol. 2011, 205, 3671-3676. [CrossRef]

22. Li, R.; Li, Z.; Zhu, Y.; Qi, K. Structure and corrosion resistance properties of Ni-Fe-B-Si-Nb amorphous composite coatings fabricated by laser processing. J. Alloys Compd. 2013, 580, 327-331. [CrossRef]

23. Bolelli, G.; Berger, L.M.; Börner, T.; Koivuluoto, H.; Lusvarghi, L.; Lyphout, C.; Markocsan, N.; Matikainen, V.; Nylén, P.; Sassatelli, P.; et al. Tribology of HVOF- and HVAF-sprayed WC-10Co4Cr hardmetal coatings: A comparative assessment. Surf. Coat. Technol. 2015, 265, 125-144. [CrossRef]

24. Milanti, A.; Matikainen, V.; Koivuluoto, H.; Bolelli, G.; Lusvarghi, L.; Vuoristo, P. Effect of spraying parameters on the microstructural and corrosion properties of HVAF-sprayed Fe-Cr-Ni-B-C coatings. Surf. Coat. Technol. 2015, 277, 81-90. [CrossRef]

25. Zheng, Z.B.; Zheng, Y.G.; Sun, W.H.; Wang, J.Q. Erosion-corrosion of HVOF-sprayed Fe-based amorphous metallic coating under impingement by a sand-containing $\mathrm{NaCl}$ solution. Corros. Sci. 2013, 76, 337-347. [CrossRef]

26. Hulka, I.; Şerban, V.A.; Secoşan, I.; Vuoristo, P.; Niemi, K. Wear properties of CrC-37WC-18M coatings deposited by HVOF and HVAF spraying processes. Surf. Coat. Technol. 2012, 210, 15-20. [CrossRef]

27. Wang, Q.; Zhang, S.; Cheng, Y.; Xiang, J.; Zhao, X.; Yang, G. Wear and corrosion performance of WC-10Co4Cr coatings deposited by different HVOF and HVAF spraying processes. Surf. Coat. Technol. 2013, 218, 127-136. [CrossRef]

28. Guo, R.Q.; Zhang, C.; Chen, Q.; Yang, Y.; Li, N.; Liu, L. Study of structure and corrosion resistance of Fe-based amorphous coatings prepared by HVAF and HVOF. Corros. Sci. 2011, 53, 2351-2356. [CrossRef]

29. Li, C.J.; Yang, G.J. Relationships between feedstock structure, particle parameter, coating deposition, microstructure and properties for thermally sprayed conventional and nanostructured WC-Co. Int. J. Refract. Met. Hard Mater. 2013, 39, 2-17. [CrossRef]

30. Liu, S.; Sun, D.; Fan, Z.; Yu, H.; Meng, H. The influence of HVAF powder feedstock characteristics on the sliding wear behaviour of WC-NiCr coatings. Surf. Coat. Technol. 2008, 202, 4893-4900.

31. Wang, Y.; Xing, Z.Z.; Luo, Q.; Rahman, A.; Jiao, J.; Qu, S.J.; Zheng, Y.G.; Shen, J. Corrosion and erosion-corrosion behaviour of activated combustion high-velocity air fuel sprayed Fe-based amorphous coatings in chloride-containing solutions. Corros. Sci. 2015, 98, 339-353. [CrossRef]

32. Bolelli, G.; Börner, T.; Milanti, A.; Lusvarghi, L.; Laurila, J.; Koivuluoto, H.; Niemi, K.; Vuoristo, P. Tribological behavior of HVOF- and HVAF-sprayed composite coatings based on Fe-Alloy + WC-12\% Co. Surf. Coat. Technol. 2014, 248, 104-112. [CrossRef]

33. Masuku, Z.H.; Olubambi, P.A.; Potgieter, J.H.; Obadele, B.A. Tribological and Corrosion Behavior of HVOF-Sprayed WC-Co-Based Composite Coatings in Simulated Mine Water Environments. Tribol. Trans. 2015, 58, 337-348. [CrossRef]

34. Wang, A.P.; Wang, Z.M.; Zhang, J.; Wang, J.Q. Deposition of HVAF-sprayed Ni-based amorphous metallic coatings. J. Alloys Compd. 2007, 440, 225-228. [CrossRef] 
35. Yingjie, W.; Gengsheng, O.; Lei, Z.; Xiaoping, W.; Hengyu, Z.; Shanlin, W. Corrosion Resistance of Coating with Fe-based Metallic Glass Powders Fabricated by Laser Spraying. J. Appl. Sci. 2013, 13, 1479-1483.

36. Manish, R.; Davim, J.P. Thermal Sprayed Coatings and Their Tribological Performances; IGI Global: Hershey, PA, USA, 2015.

37. Lyphout, C.; Sato, K. Screening design of hard metal feedstock powders for supersonic air fuel processing. Surf. Coat. Technol. 2014, 258, 447-457. [CrossRef]

38. Schneider, C.A.; Rasband, W.S.; Eliceiri, K.W. NIH Image to ImageJ: 25 years of image analysis. Nat. Method. 2012, 9, 671-675. [CrossRef]

39. Jones, D.A. Principles and Prevention of Corrosion: Pearson New International Edition, 2nd ed.; Prentice Hall: Englewood Cliffs, NJ, USA, 1995.

40. Zhao, L.; Lugscheider, E. Influence of the spraying processes on the properties of 316L stainless steel coatings. Surf. Coat. Technol. 2003, 162, 6-10. [CrossRef]

41. Redjdal, O.; Zaid, B.; Tabti, M.S.; Henda, K.; Lacaze, P.C. Characterization of thermal flame sprayed coatings prepared from FeCr mechanically milled powder. J. Mater. Process. Technol. 2013, 213, 779-790. [CrossRef]

42. Zhao, W.M.; Wang, Y.; Dong, L.X.; Wu, K.Y.; Xue, J. Corrosion mechanism of NiCrBSi coatings deposited by HVOF. Surf. Coat. Technol. 2005, 190, 293-298. [CrossRef]

43. Lee, S.M.; Lee, W.G.; Kim, Y.H.; Jang, H. Surface roughness and the corrosion resistance of $21 \mathrm{Cr}$ ferritic stainless steel. Corros. Sci. 2012, 63, 404-409. [CrossRef]

44. Souza, V.A.D.; Neville, A. Linking electrochemical corrosion behaviour and corrosion mechanisms of thermal spray cermet coatings (WC-CrNi and WC/CrC-CoCr). Mater. Sci. Eng. A 2003, 352, 202-211. [CrossRef]

45. Zhang, C.; Chan, K.C.; Wu, Y.; Liu, L. Pitting initiation in Fe-based amorphous coatings. Acta Mater. 2012, 60, 4152-4159. [CrossRef]

46. Liu, L.; Zhang, C. Fe-based amorphous coatings: Structures and properties. Thin Solid Films 2014, 561, 70-86. [CrossRef]

47. Sadeghimeresht, E.; Markocsan, N.; Nylén, P.; Björklund, S. Corrosion performance of bi-layer $\mathrm{Ni} / \mathrm{Cr} 2 \mathrm{C} 3-\mathrm{NiCr}$ HVAF thermal spray coating. Appl. Surf. Sci. 2016, 369, 470-481. [CrossRef]

48. Bergan, Z.; Trdan, U.; Grum, J. Effect of high-temperature furnace treatment on the microstructure and corrosion behavior of NiCrBSi flame-sprayed coatings. Corros. Sci. 2014, 88, 372-386. [CrossRef]

49. Niaz, A.; Khan, S.U. A Comprehensive Pitting Study of High Velocity Oxygen Fuel Inconel 625 Coating by Using Electrochemical Testing Techniques. J. Mater. Eng. Perform. 2015, 25, 280-289. [CrossRef]

50. Brioua, S.; Belmokre, K.; Debout, V.; Jacquot, P.; Conforto, E.; Touzain, S.; Creus, J. Corrosion behavior in artificial seawater of thermal-sprayed WC-CoCr coatings on mild steel by electrochemical impedance spectroscopy. J. Solid State Electrochem. 2011, 16, 633-648. [CrossRef]

51. Yang, Y.; Zhang, C.; Peng, Y.; Yu, Y.; Liu, L. Effects of crystallization on the corrosion resistance of Fe-based amorphous coatings. Corros. Sci. 2012, 59, 10-19. [CrossRef]

52. Zhang, J.; Desai, V. Evaluation of thickness, porosity and pore shape of plasma sprayed TBC by electrochemical impedance spectroscopy. Surf. Coat. Technol. 2005, 190, 98-109. [CrossRef]

53. Lvovich, V.F. Impedance Spectroscopy: Applications to Electrochemical and Dielectric Phenomena; John Wiley \& Sons: Hoboken, NJ, USA, 2012.

(C) 2016 by the authors; licensee MDPI, Basel, Switzerland. This article is an open access article distributed under the terms and conditions of the Creative Commons by Attribution (CC-BY) license (http://creativecommons.org/licenses/by/4.0/). 